\title{
Study on Water Transport Mechanisms of the PEMFC Based on a Visualization Platform and Water Balance Model
}

\author{
Xin Zhao (i), Ruidi Wang, Yanyi Zhang, Dong Hao, and Zirong Yang \\ China Automotive Technology and Research Center Co. Ltd., Tianjin 300300, China \\ Correspondence should be addressed to Xin Zhao; zhaoxin2019@catarc.ac.cn
}

Received 5 July 2021; Revised 3 September 2021; Accepted 9 October 2021; Published 8 November 2021

Academic Editor: Rui Wu

Copyright (c) 2021 Xin Zhao et al. This is an open access article distributed under the Creative Commons Attribution License, which permits unrestricted use, distribution, and reproduction in any medium, provided the original work is properly cited.

\begin{abstract}
It is widely acknowledged that the water balance issue is extremely important for improving the performance and durability of the proton exchange membrane fuel cell. In the presented paper, the visualization platform of the single fuel cell and the water balance model were built to investigate the water transport mechanisms. A transparent $25 \mathrm{~cm}^{2}$ single fuel cell with serpentine flow channels was adopted. Based on the experimental data, firstly, the change rate of water content in the fuel cell was calculated quantitatively and the reliability of the water balance model was rigorously validated. Then, the water state in the fuel cell as the qualitative finding was observed online to assist the research of water transport mechanisms. Finally, the effects of inlet gas temperature, inlet gas humidity, and hydrogen/air stoichiometry on the EIS, the voltage, and the water content in the fuel cell were studied quantitatively, respectively. The corresponding relationship between the performance and the water content in the fuel cell was obtained.
\end{abstract}

\section{Introduction}

The proton exchange membrane fuel cell (PEMFC) is a device that directly converts the chemical energy of fuel and oxidant into the electrical energy by the electrochemical reactions $[1,2]$. Due to the advantages of high energy density, zero emissions, and low operating temperatures, the PEMFC is considered as a promising alternative to solve the global environmental problems. Although some progress of the PEMFC has been made in the past 30 years, its large-scale commercialization is still hindered by the challenges of high material cost, low output performance, and unsatisfactory durability. It is known that water is one of the important products of electrochemical reactions [3]. On the one hand, the protons will be prevented from entering the catalyst surface due to the membrane drying. Also, the irreversible degradation of the membrane may also be caused by the membrane drying [4-6]. On the other hand, the liquid water existing and accumulating in the flow channel or the electrode pore must be removed by evaporation, water vapor diffusion, or capillary transport.
The mechanical degradation of membrane electrode assembly (MEA) and the local lack of fuel and oxidant may be caused by the long-term operation of the fuel cell under a water flooding condition [7-9]. In order to achieve the best performance of the vehicle fuel cell, the inlet gas humidity, operating temperature, current density, and hydrogen/air stoichiometry must be maintained appropriate. The higher the current density is, the more the water produced by the electrochemical reactions is. The excess water vapor is easy to be condensed in the flow channel at low operating temperature or high inlet gas humidity. The flow and discharge of water will be hindered by low hydrogen/air stoichiometry. Due to the abovementioned conditions, the water flooding may occur in the gas diffusion layer (GDL) and the flow channel. The transmission of reactants to the reaction interface will be hindered. Then, the fuel cell performance decreases. On the contrary, if the generated or condensed water reduces or the exhausted water increases, the membrane drying may occur and the fuel cell performance decreases. The common health faults such as water flooding and membrane drying which affect the stable 
operation and life of the fuel cell appear easily in the vehicle fuel cell. Therefore, it is extremely important to understand the water transport mechanisms for improving the fuel cell performance as well as durability.

So far, the experimental research on the internal water state of the fuel cell has been taken into account and some good results have been achieved. A variety of methods for observing the internal water state of the single fuel cell have been utilized, including neutron imaging, computed tomography (CT), nuclear magnetic resonance imaging (NMRI), and visualization technology of the transparent fuel cell [10-13]. Compared with the indirect observation methods, the visualization method makes the observation become more intuitive in the flow channel, which greatly reduces the requirement for test instruments. The real-time flow phenomena in the operation process can be observed by designing different flow channels, changing different GDL materials, or adjusting the inlet/outlet pipe positions. The design of flow channels has been focused on at the early research of water transmission in the flow channel. The flow channels are usually designed as parallel, serpentine, interdigitated, or the abovementioned alternating or combined forms. The water removal effect of parallel flow channels is not obvious, but the pressure drop is small. The serpentine flow channels have strong water removal capacity and large pressure drop. The interdigitated flow channels have good water removal effect, but the pressure drop is too large, especially for the largearea PEMFC. Based on the importance of the water removal effect of flow channels, the serpentine flow channels are often used to ensure the water removal capacity of the fuel cell. In 2003, the visualization method was firstly used to observe the formation and flow of liquid water in the cathode flow field [7]. In 2007, Spernjak et al. [14] used the polycarbonate end plate as the visual window to study the two-phase flow dynamics of various GDL materials. In 2009, Guo et al. [15] designed the cathode and anode graphite plates with serpentine flow channels of the visual single fuel cell. Through the visualization observations of gas-liquid two-phase flow in the cathode flow field under normal gravity and microgravity conditions, it was found that the liquid water accumulating at the flow channel bottom was easier to be discharged under microgravity conditions. In 2015, Wang et al. [16] carried out the visualization designs for the anode, cathode, and both sides of the single fuel cell, respectively. In 2016, Ruan et al. [17] used the hollow polycarbonate plate as the end plate and introduced the heated glycerol solution into the solution cavity. The observation difficulty caused by the fogging of the visual window was avoided which greatly promotes the development of single fuel cell visualization technology. In 2017, Huang et al. [18] designed a visual fuel cell using the stainless steel plate as the plate and the transparent acrylic plexiglass as the visual window. The drainage performance of the fuel cell at $60^{\circ} \mathrm{C}$ was obtained. In 2018, Rao et al. [19] used a titanium plate with high conductivity and chemical stability and a $5 \mathrm{~mm}$ transparent acrylic visual window to study the effect of torque applied on the bolt on the fuel cell performance.

With the rapid development of numerical simulation, some mathematical models were built to simulate the water transport process in the fuel cell. In 2000, Wu et al. [20] proposed a two-dimensional mass transport mathematical model of fuel cell to research the water management technology. In 2008, Hong and Liu [21] established a mass transport mathematical model to study the water management of the PEMFC. In 2020, Kellegoz [22] developed a mathematical model of PEMFC. The effect of various operating parameters on the performance was investigated.

It is convenient for real-time and intuitively understanding the appearance process of liquid water in the fuel cell by the introduction of a transparent structure in the visual single fuel cell. However, there are also some problems in the design and test of the visual single fuel cell. First of all, as a flow field, the texture of the graphite plate is brittle and the risk of damage is high. The thermal conductivity and electrical conductivity of graphite plate is slightly poor. Secondly, the durability of metal plate is relatively poor, and the requirements for processing technology are high. Finally, after introducing the transparent structure, the performance of the visual single fuel cell decreases. The effect factor may be the deformation of the graphite hollow plate and transparent end plate. Therefore, the optimization and further research of the visual single fuel cell system is very important.

In this paper, the visualization platform of the single fuel cell and the water balance model are built to investigate the water transport mechanisms. A transparent $25 \mathrm{~cm}^{2}$ single fuel cell with serpentine flow channels is adopted. Based on the experimental data, firstly, the change rate of water content in the fuel cell is calculated quantitatively and the reliability of water balance model is rigorously validated. Additionally, the water state in the fuel cell as the qualitative finding is observed online. Finally, the effects of inlet gas temperature, inlet gas humidity, and hydrogen/air stoichiometry on the EIS, the voltage, and the water content in the fuel cell are studied quantitatively, respectively. The corresponding relationship between the performance and the water content in the fuel cell is obtained.

\section{Experimental Methodology}

\subsection{Test Equipment}

2.1.1. Visual Single Fuel Cell. In the present study, the cathode visual single fuel cell is designed. The conventional end plate is replaced with a transparent device. As shown in Figure 1, the structure of the visual single fuel cell from outside to inside is the transparent end plate (with silicone rubber sealing ring)-metal hollowed out plate-polytetrafluoroethylene sealing gasket, MEA. The active area of MEA is $55 \mathrm{~cm}^{2}$. The Pt loading of MEA for the anode and cathode are both $0.5 \mathrm{mgcm}^{-2}$. The carbon fiber paper is used as GDL/microporous layer (MPL). The composition of the catalyst is $60 \% \mathrm{Pt} / \mathrm{C}$. The serpentine flow channels and the metal hollow plate are used.

2.1.2. Water Recover Device for the Fuel Cell. The special water recover devices for the fuel cell are devised to solve the problem of the water recovery for the outlet gas, as shown in Figure 2. It is helpful to measure the amount of exhausted water in both the liquid and vapor phase, so as to realize the online measurement technology for the water content in the fuel cell. 

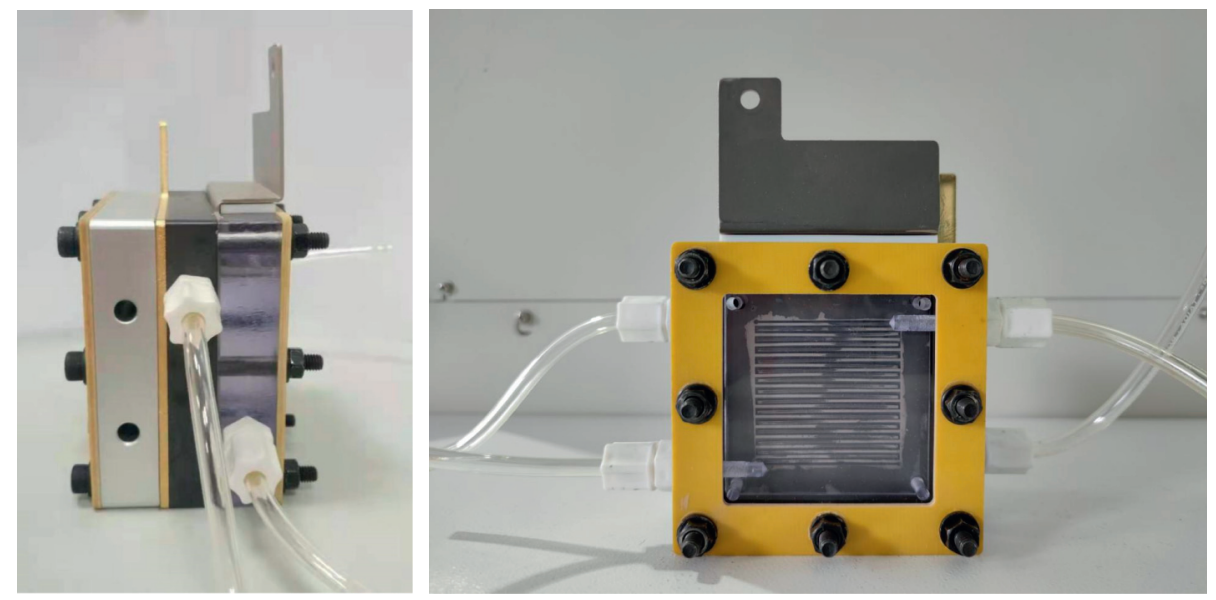

FIgURE 1: Structure of the cathode visual single fuel cell.

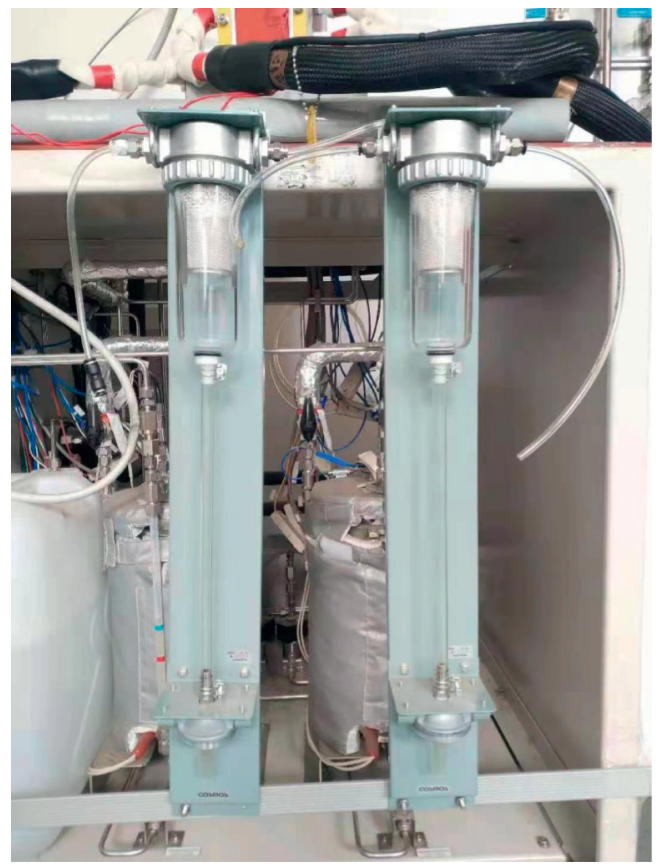

FIgURE 2: Structure of the water recover devices for the fuel cell.

2.1.3. Visualization Platform of the Single Fuel Cell. The equipment drawing of the visualization platform of the single fuel cell is given in Figure 3. It includes the adjustable hydrogen input device, the adjustable air input device, the fuel cell reaction test platform, the water recovery devices, and the video recorder. The adjustable hydrogen input device includes the hydrogen storage device, the reduction valve (Tescom 44-2260-242-009), and the hydrogen flow meter (Alicat KM3100). The adjustable air input device includes the air filter and the air flow meter (Alicat KM3100). The fuel cell reaction test platform is the AutoPEM 300W fuel cell reaction text platform of Toyo Corporation. The control accuracy of hydrogen and air flow is $\pm 1 \%$ of FS. The amount of exhausted water, the internal water state, the voltage, and the EIS of PEMFC can be obtained by the visualization platform of the single fuel cell.
2.2. Test Method. This test is conducted to verify the reliability of the water balance model, observe the online water state in the fuel cell, and investigate the water transport mechanisms. Firstly, the fuel cell reaction test platform is opened. Then, according to the target volume flow value of hydrogen and air, the required volume flow value of hydrogen and air are accessed to the fuel cell reaction test platform. After the inlet reaction gas reaches the set value, the parameters of the specified condition are set up. Subsequently, the fuel cell is operated and the outlet hydrogen and air are accessed into the water recovery devices of hydrogen and air, respectively. The exhausted water is collected by using the water recovery devices of hydrogen and air every $30 \mathrm{~min}$. The video recorder is used to record the water state in the fuel cell. EIS is measured after the end of every test. Finally, the water content in the fuel cell is calculated by the water balance model. 
2.3. Test Conditions. The operation conditions of the visual single fuel cell are shown in Table 1 . The operation current density is $0.8 \mathrm{Acm}^{-2}$.

\section{Water Balance Model}

Based on the operating principle of the fuel cell, the water mainly comes from the electrochemical reactions and the inlet reaction gas. Then, a part of water is left in the fuel cell and the other is brought out by the outlet gas/water. Figure 4 is the schematic of the water balance model.

In view of the water balance relationship of the fuel cell, the water balance model is

$$
m_{1, \text { water }}=m_{\text {in,water }}+m_{\text {gen,water }}-\left(m_{\text {out,water }}+m_{\text {out,gas }}\right),
$$

where $m_{1 \text {,water }}$ is the amount of water left in the fuel cell, $m_{\text {in,water }}$ is the amount of water brought in by the inlet reaction gas, $m_{\text {gen,water }}$ is the amount of water generated by the electrochemical reactions, and $m_{\text {out,water }}$ and $m_{\text {out,gas }}$ are the amount of water brought out by the outlet water and gas, respectively.

Due to the inlet reaction gas including hydrogen and air, the amount of water brought in by the inlet reaction gas is

$$
m_{\text {in,water }}=m_{\text {in,water, } H_{2}}+m_{\text {in,water,air }}
$$

where $m_{\text {in,water, } H_{2}}$ and $m_{\text {in,water,air }}$ are the amount of water brought in by the inlet hydrogen and air, respectively. According to the basic principle of engineering thermodynamics, the amount of water brought in by the inlet reaction gas is

$$
m_{\mathrm{in}, \text { water }}=\frac{M_{\mathrm{H}_{2}} p_{v p, H_{2}}}{M_{\mathrm{air}}\left(p_{c, H_{2}}-p_{v p, H_{2}}\right)} m_{\mathrm{in}, H_{2}}+\frac{M_{\text {water }} p_{v p, \text { air }}}{M_{\mathrm{air}}\left(p_{c, \text { air }}-p_{v p, \text { air }}\right)} m_{\mathrm{in}, \mathrm{air}},
$$

where $M_{\mathrm{H}_{2}}$ is the molecular weight of hydrogen, $M_{\text {water }}$ is the molecular weight of water, $M_{\text {air }}$ is the molecular weight of air, $p_{v p, \mathrm{H}_{2}}$ is the water vapor pressure in hydrogen, $p_{\mathrm{H}_{2}}$ is the hydrogen pressure, $p_{v p \text {,air }}$ is the water vapor pressure in air, $p_{\text {air }}$ is the air pressure, and $\mathrm{m}_{\mathrm{in}, H_{2}}$ and $\mathrm{m}_{\text {in,air }}$ are the amount of the inlet hydrogen and air, respectively.

In line with the electrochemical reaction equations, the amount of water generated by the electrochemical reactions is

$$
m_{\text {gen,water }}=\frac{M_{\text {water }}}{M_{H_{2}}} \dot{m}_{\text {in }, H_{2}} t=\frac{M_{\text {water }}}{M_{H_{2}}} \rho_{H_{2}} \dot{V}_{\text {in }, H_{2}} t=\frac{M_{\text {water }}}{M_{H_{2}}} \frac{p_{H_{2}} M_{H_{2}}}{R T} \dot{V}_{\text {in }, H_{2}} t \text {, }
$$

where $p_{H_{2}}$ is the hydrogen pressure, $R$ is the universal gas constant, and $T$ is the temperature.

The amount of water brought out by the outlet gas $m_{\text {out,gas }}$ is

$$
m_{\text {out,gas }}=\frac{M_{\text {water }} p_{\mathrm{vp}, \text { air }}^{\prime} p^{\prime}}{M_{\text {air }}\left(p_{\text {air }}^{\prime}-p_{\text {vp,air }}^{\prime}\right)} \mathrm{m}_{\text {out,air }}^{\prime}
$$

The change rate of water content in the fuel cell $\dot{\delta} \dot{m}_{l, \text { water }}$ is $\dot{\delta m_{l, w a t e r}}=\delta \dot{m}_{\mathrm{in}, \text { water }}+\delta \dot{m}_{\mathrm{gen}, \mathrm{water}}-\left(\delta \dot{m}_{\mathrm{out}, \mathrm{water}}+\delta \dot{m}_{\text {out,vapor }}\right)$.

\section{Results and Analysis}

4.1. Water Balance in the Fuel Cell. If the water brought in the fuel cell is more or brought out is less, the internal water of the fuel cell will become more and the water flooding may occur. In contrast, the internal water of the fuel cell will be less and the membrane drying may arise [23]. Based on the operation theory of fuel cell, the water content in the fuel cell should remain unchanged in the stable operation stage $\left(\dot{\delta} m_{l, \text { water }}=0\right)[24,25]$. As shown in Figure 5, the change rate of water content in the fuel cell under different operation conditions is calculated by the water balance model. From the experiment results, the change rate of water content in the fuel cell under different operation conditions slightly fluctuate up and down near zero. It is in line with the theoretical analysis which proved the model correctness.

4.2. Water State in the Fuel Cell. Taking advantage of the visual single fuel cell, the water state in the fuel cell under different operation conditions can be directly observed. To more clearly observe the water accumulating in the flow channel, the image of the specific flow channel at inlet gas temperature $45^{\circ} \mathrm{C}$ is shown in Figure 6. The water accumulates in the flow channel and then purges along the flow channel by gas flow. As shown in Figures 7(a) and 7(b), the water content in the fuel cell at inlet 


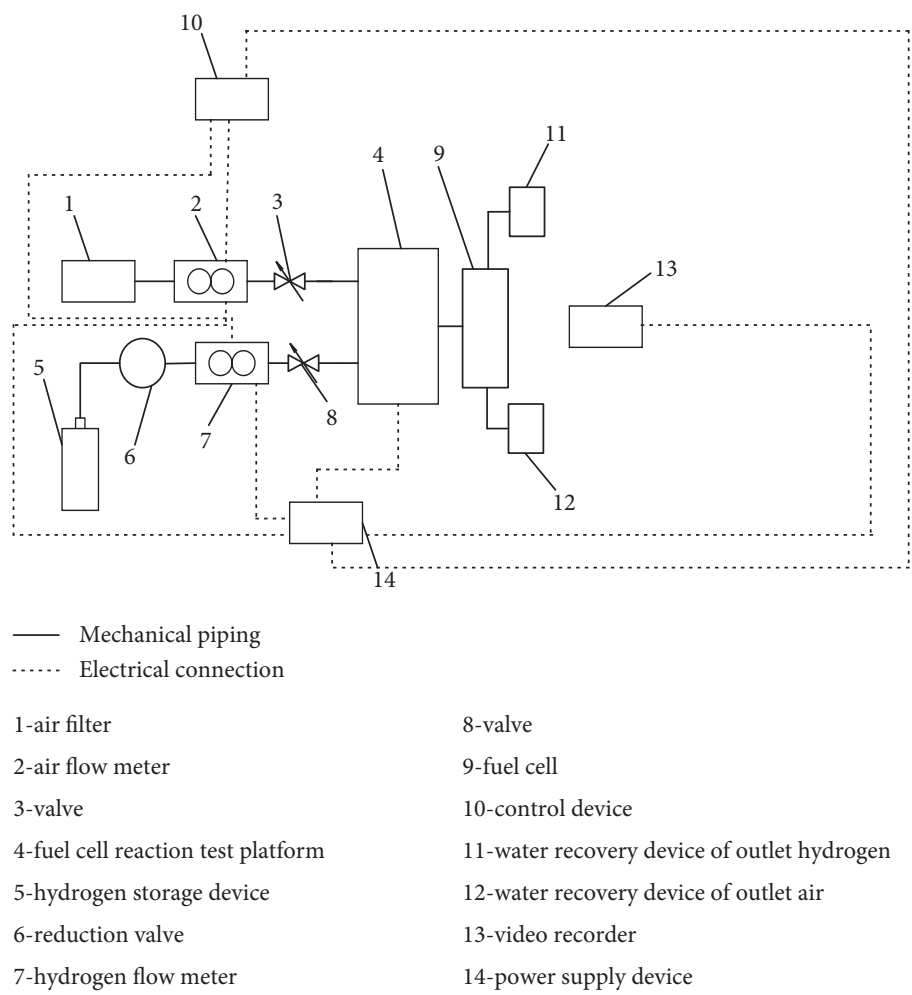

(a)

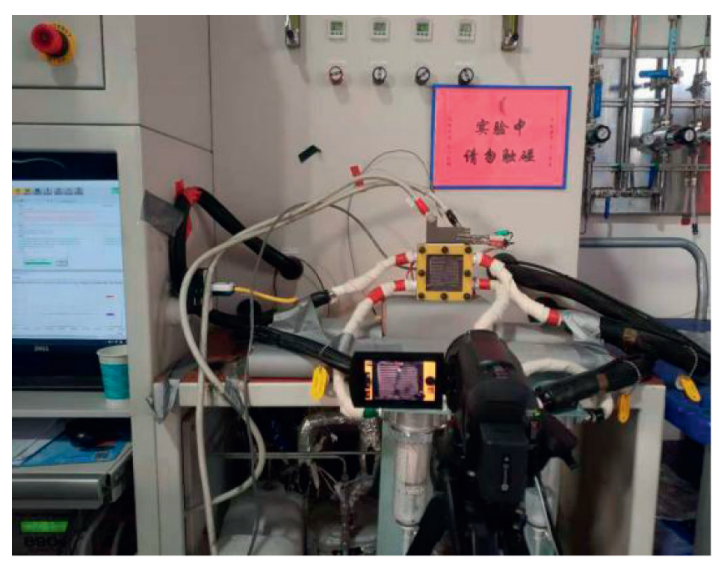

(b)

Figure 3: Visualization platform of the single fuel cell.

TABLE 1: Different operation conditions of the visual single fuel cell.

\begin{tabular}{|c|c|c|c|c|}
\hline No. & Inlet gas temperature & Inlet gas humidity & Hydrogen stoichiometry & Air Stoichiometry \\
\hline Case_1 & $45^{\circ} \mathrm{C}$ & & & \\
\hline Case_2 & $65^{\circ} \mathrm{C}$ & $100 \%$ & & \\
\hline Case_3 & $85^{\circ} \mathrm{C}$ & & 15 & \\
\hline Case_4 & & $20 \%$ & 1.5 & \\
\hline Case_5 & $75^{\circ} \mathrm{C}$ & $50 \%$ & & 2.5 \\
\hline Case_6 & & $80 \%$ & & \\
\hline Case_7 & & & 2.0 & \\
\hline Case_8 & $75^{\circ} \mathrm{C}$ & $100 \%$ & 1.2 & \\
\hline Case_9 & & & 1.05 & \\
\hline Case_10 & & & & 3.5 \\
\hline Case_11 & $75^{\circ} \mathrm{C}$ & $100 \%$ & 1.5 & 3.0 \\
\hline Case_12 & & & & 2.0 \\
\hline
\end{tabular}

gas temperature $65^{\circ} \mathrm{C}$ is less than that at inlet gas temperature $45^{\circ} \mathrm{C}$. It is because the partial pressure of saturated water vapor in the gas increases when the inlet gas temperature increases. The gas flow rate is raised which is conducive to the purging of liquid water. In Figures 7(c) and 7(d), it is shown that the water content in the fuel cell at inlet gas humidity $80 \%$ is less than that at inlet gas humidity $20 \%$. On the one hand, the high inlet gas humidity will bring more water into the fuel cell. On the other hand, the partial pressure of water vapor in the gas increases and the water vapor content in the outlet gas increases. There are constraints between them. The water at hydrogen stoichiometry 2.0 is more than that at hydrogen stoichiometry 1.05 in
Figures 7(e) and 7(f). The main reason is that the water generation rate is fast at high hydrogen stoichiometry. As shown in Figures $7(\mathrm{~g})$ and $7(\mathrm{~h})$, the water at air stoichiometry 2.0 is less than that at air stoichiometry 3.5. It is because that the water generation rate is fast at the high air stoichiometry.

\subsection{EIS}

4.3.1. Inlet Gas Temperature. Figure 8 illustrates the effect of inlet gas temperature on the voltage, the water content in the fuel cell, the EIS, and the ohmic resistance. From the results, it can be seen that the effect of inlet gas temperature on the 


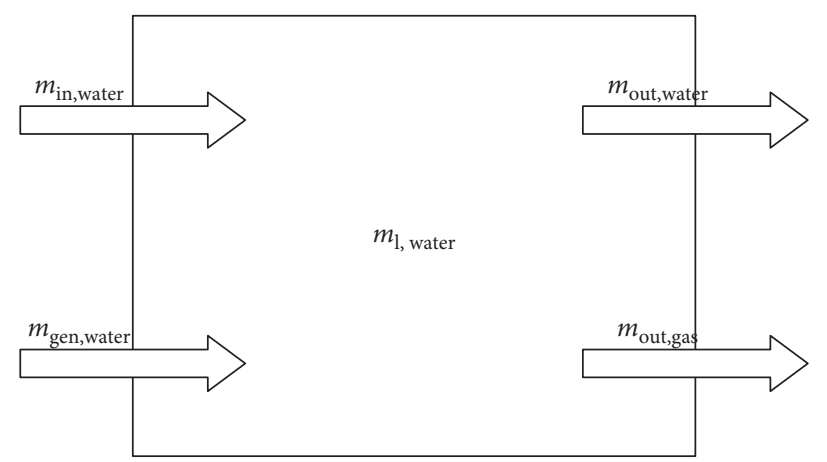

FIgURE 4: Schematic of the water balance model.

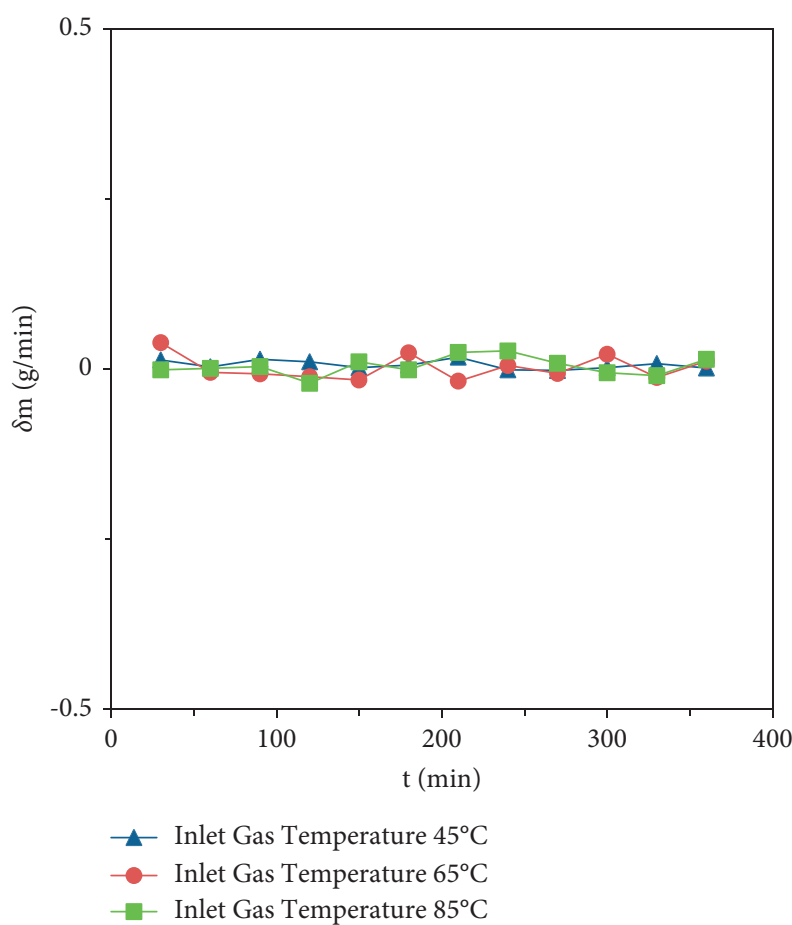

(a)

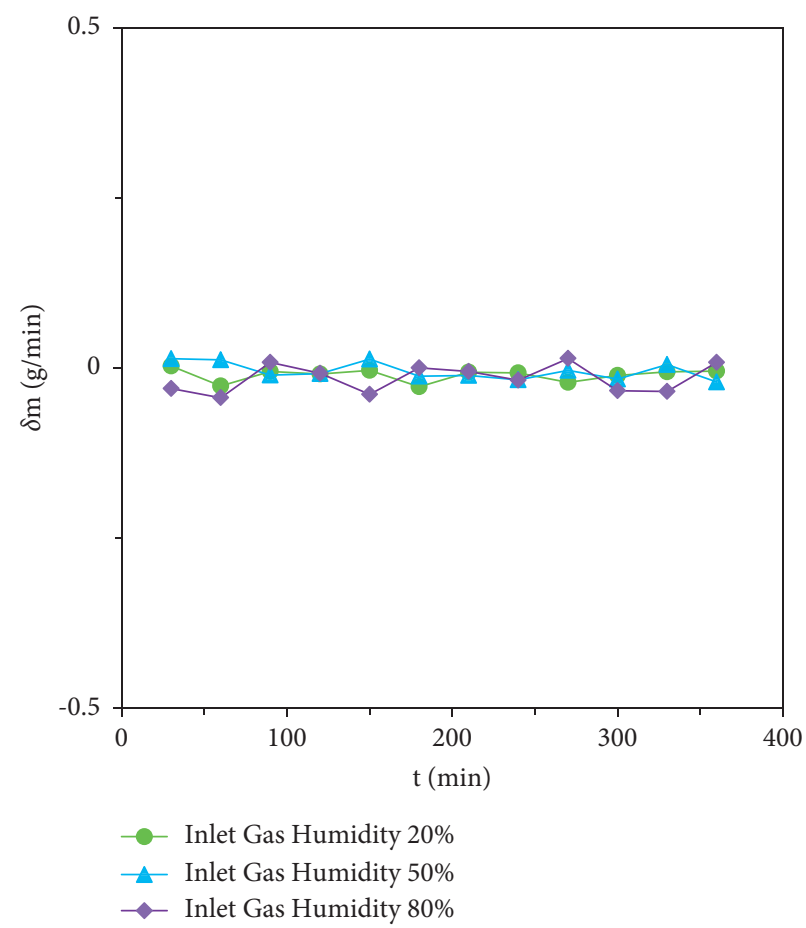

(b)

Figure 5: Continued. 


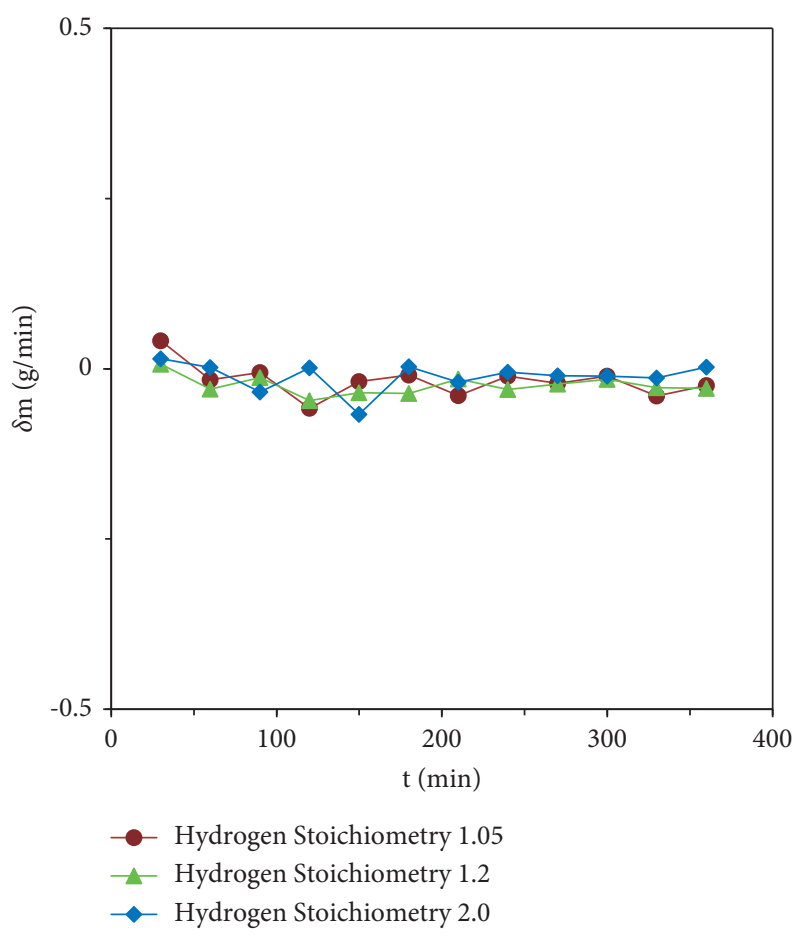

(c)

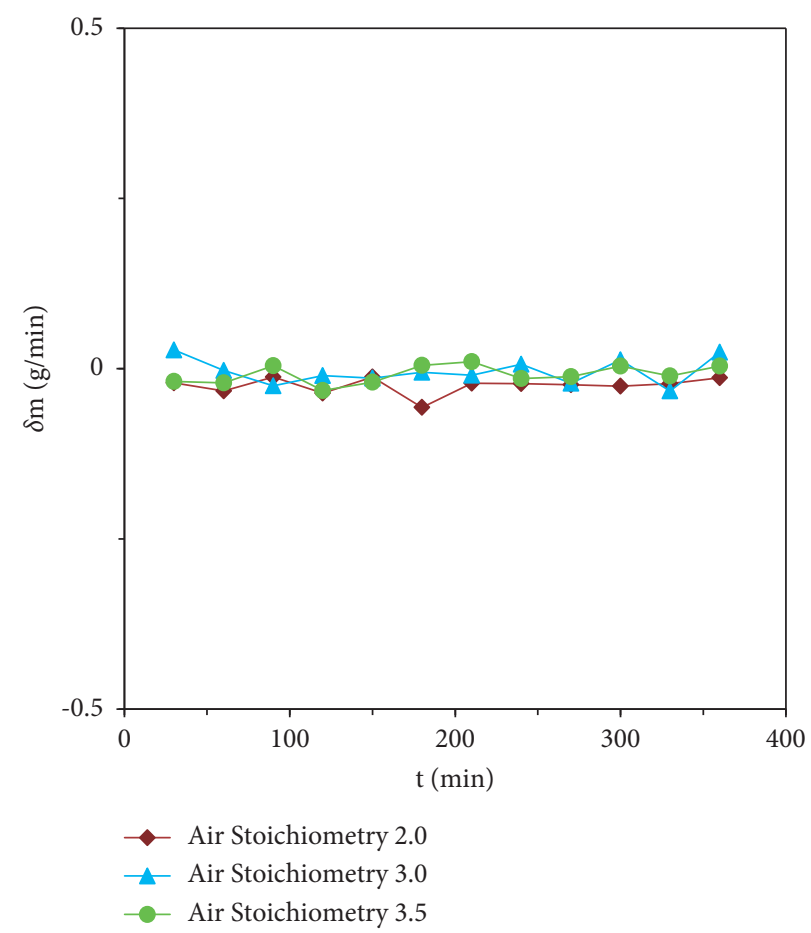

(d)

FIGURE 5: Change rate of water content in the fuel cell under different operation conditions. (a) Inlet gas temperature. (b) Inlet gas humidity. (c) Hydrogen stoichiometry. (d) Air stoichiometry.

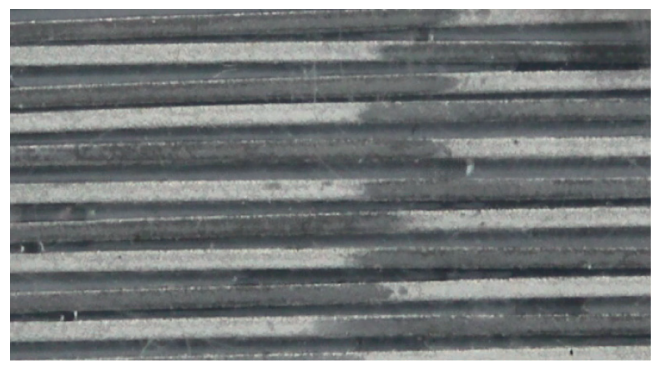

Figure 6: Image of the water accumulating in the specific flow channel at inlet gas temperature $45^{\circ} \mathrm{C}$.

performance and the water content in the fuel cell is in volatility. At the condition of inlet gas temperature $65^{\circ} \mathrm{C}$, the performance of the fuel cell is the best and the water content in the fuel cell is the least. When the inlet gas temperature increases, the partial pressure of saturated water vapor in the gas increases. On the one hand, the gas in the flow channel is increased and the gas flow rate rises which is conducive to the purging of liquid water. On the other hand, more liquid water can be obtained by the electrochemical reactions at high inlet gas temperature. There are constraints between them. The experiment results show that the ohmic resistance is not significantly affected at an inlet gas temperature of $45^{\circ} \mathrm{C}-85^{\circ} \mathrm{C}$.

4.3.2. Inlet Gas Humidity. Figure 9 shows that the effect of inlet gas humidity on the voltage, the water content in the fuel cell, the EIS, and the ohmic resistance. From the experiment data, it can be seen that the higher the inlet air humidity is, the better the performance and the least the water content in the fuel cell are. The best performance and the least water content in the fuel cell occur at the operation condition of inlet gas humidity $80 \%$. When the inlet gas humidity rises, the proton conductivity is higher which is beneficial to improve the fuel cell performance. Although the water brought in the fuel cell is more at high inlet gas humidity, the partial pressure of water vapor in the gas increases with the increase in inlet gas humidity, and the water vapor content in the exhausted gas increases. Therefore, the water content in the fuel cell decreases. As shown in Figure 9(b), the ohmic resistance decreases as the inlet gas humidity increases.

4.3.3. Hydrogen Stoichiometry. The effect of hydrogen stoichiometry on the voltage, the water content in the fuel cell, the 


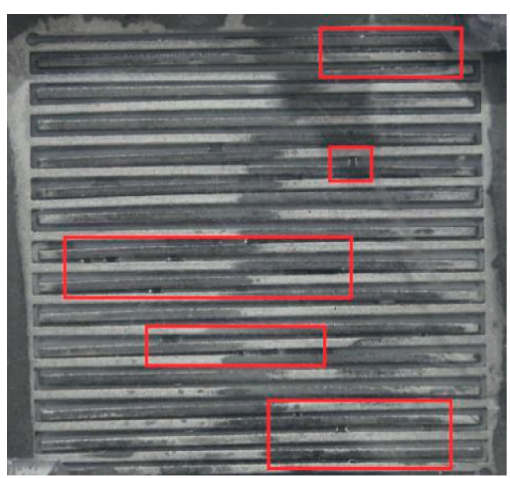

(a)

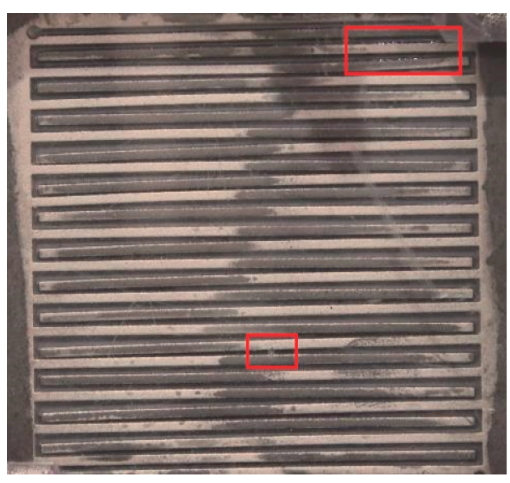

(d)

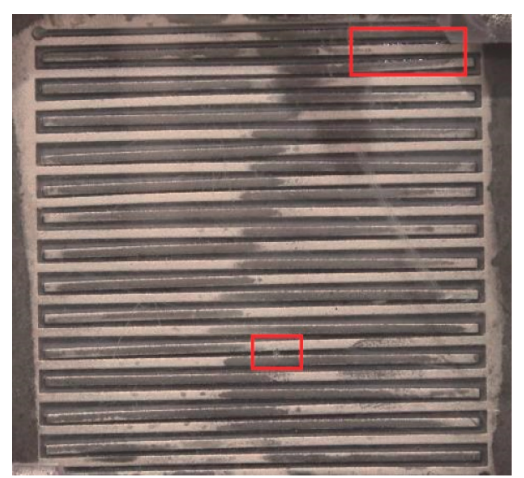

(b)

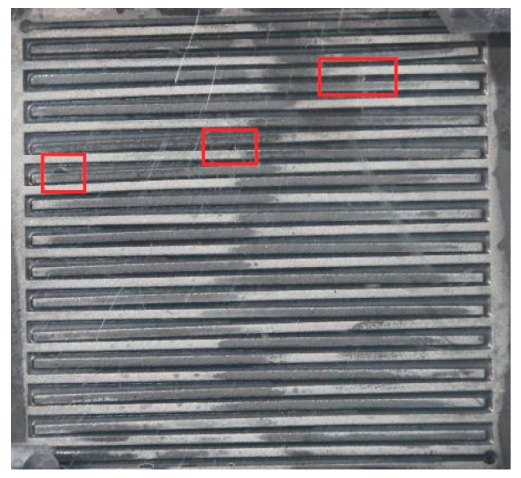

(e)

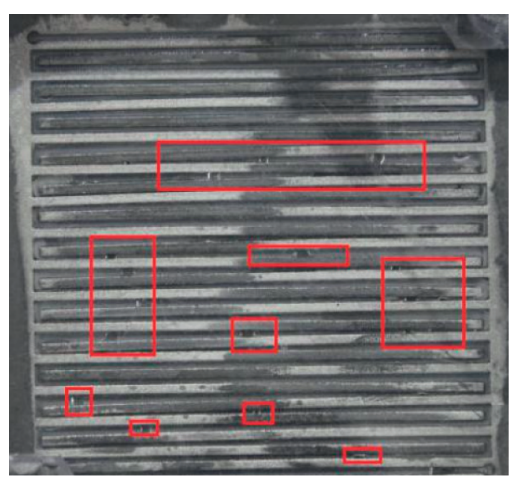

(c)

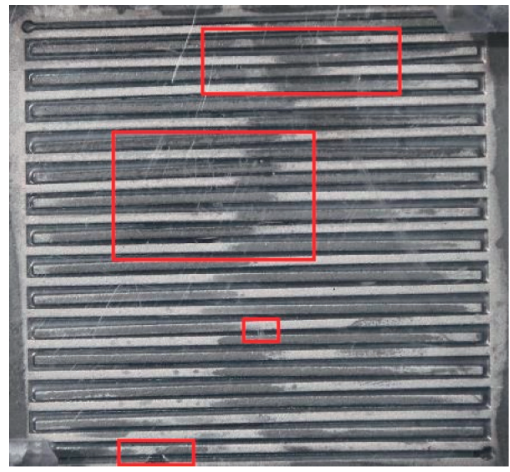

(f)

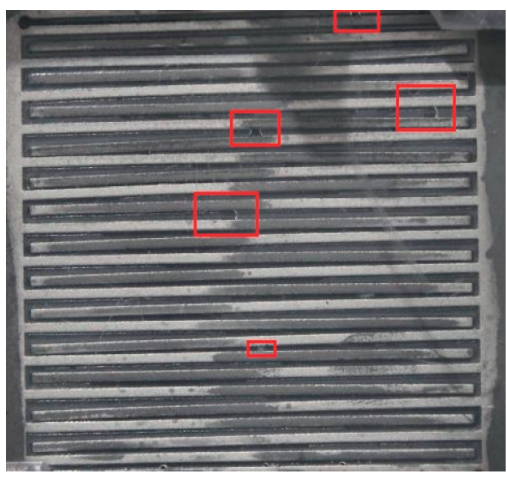

(g)

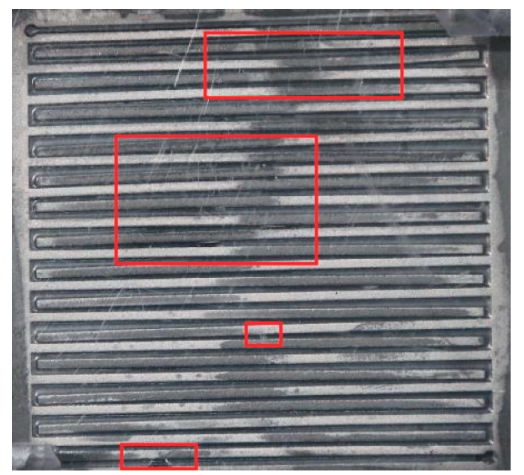

(h)

Figure 7: Water state in the fuel cell under different operation conditions at the same time. (a) Inlet gas temperature $45^{\circ} \mathrm{C}$. (b) Inlet gas temperature $65^{\circ} \mathrm{C}$. (c) Inlet gas humidity $20 \%$. (d) Inlet gas humidity $80 \%$. (e) Hydrogen stoichiometry 1.05. (f) Hydrogen stoichiometry 2.0. (g) Air stoichiometry 2.0. (h) Air stoichiometry 3.5.

EIS, and the ohmic resistance is given in Figure 10. The fuel cell performance decreases with the decrease in hydrogen stoichiometry. The fluctuation effect of hydrogen stoichiometry on the water content in fuel cell is shown. At hydrogen stoichiometry 2.0 , the performance of the fuel cell is the best and the water content in the fuel cell is more. There is a lot of unreacted residual hydrogen in the flow channel which is beneficial to the purging of liquid water. The voltage can be maintained without rapid decline, and the performance of fuel cell is good. However, when the hydrogen stoichiometry is increased, the hydrogen reaction rate is fast. Therefore, the water content in the fuel cell shows a fluctuated change. Furthermore, the ohmic resistance is relatively not influenced at a hydrogen stoichiometry of 1.05-2.0.
4.3.4. Air Stoichiometry. Figure 11 demonstrates that the effect of air stoichiometry on the voltage, the water content in the fuel cell, the EIS, and the ohmic resistance. As the air stoichiometry decreases, the fuel cell performance is declined. The water content in the fuel cell kept on fluctuating. The fuel cell performance is the best at air stoichiometry 3.5. At high air stoichiometry, there is a large amount of unreacted residual air in the flow channel, which has a good purging effect on the liquid water. The voltage can be maintained without rapid decline, and the fuel cell performance is good. The water content in the fuel cell is most at air stoichiometry 3.0. On the one hand, the unreacted residual air purges the liquid water. On the other hand, the reaction rate of air is high 

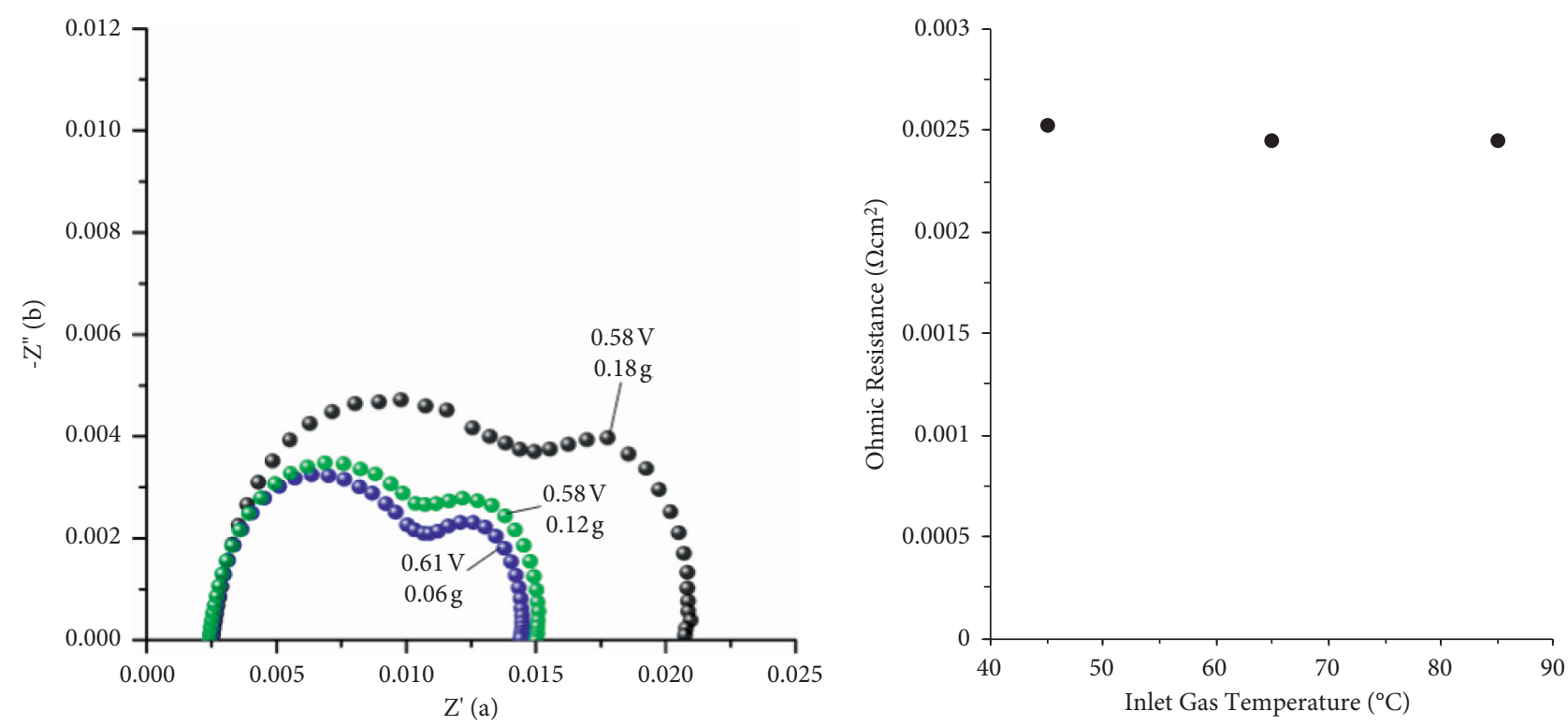

- Inlet Gas Temperature $45^{\circ} \mathrm{C}$

- Inlet Gas Temperature $65^{\circ} \mathrm{C}$

- Inlet Gas Temperature $85^{\circ} \mathrm{C}$

(a)

(b)

FIGURE 8: Effect of inlet gas temperature on the voltage, water content in the fuel cell, EIS, and ohmic resistance (inlet gas humidity $100 \%$, hydrogen stoichiometry 1.5, and air stoichiometry 2.5). (a) EIS. (b) Ohmic resistance.

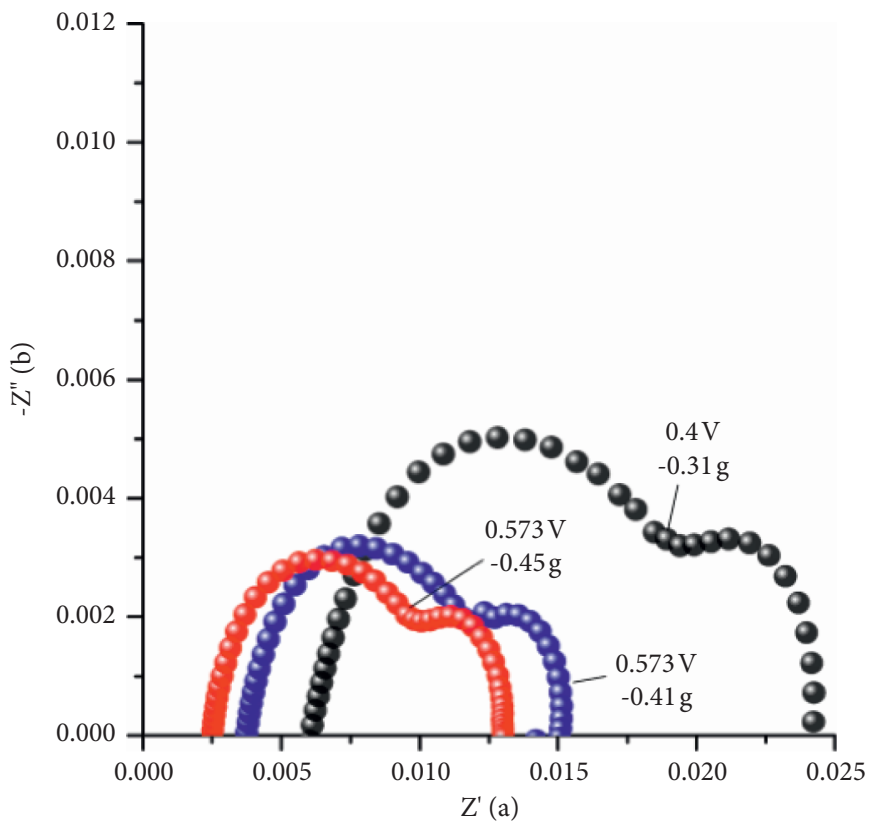

- Inlet Gas Humidity $20 \%$

- Inlet Gas Humidity $50 \%$

- Inlet Gas Humidity $80 \%$

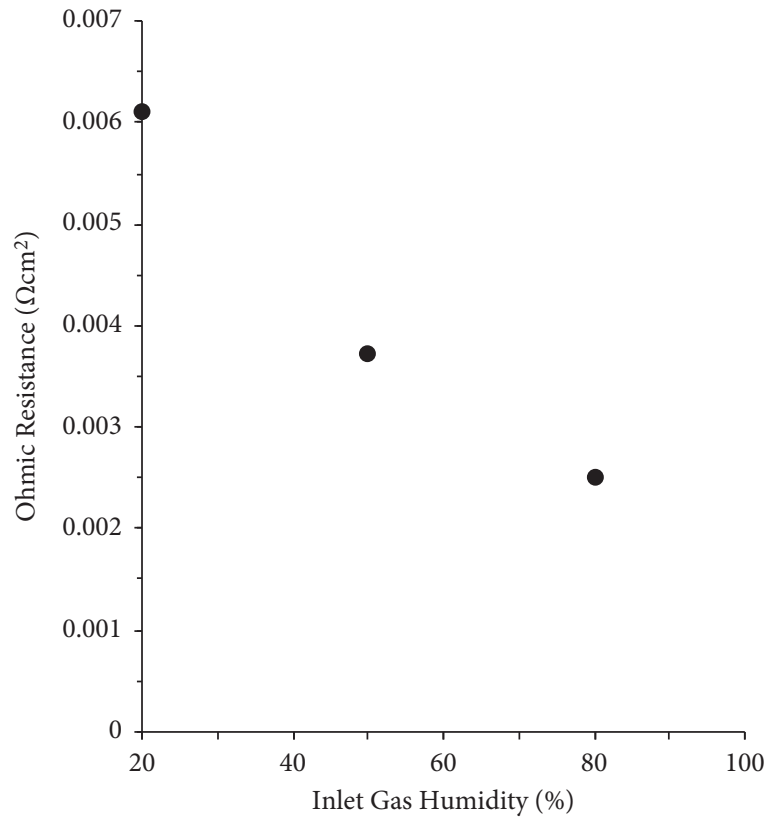

(b)

FIGURE 9: Effect of inlet gas humidity on the voltage, water content in the fuel cell, EIS, and ohmic resistance (inlet gas temperature $75^{\circ} \mathrm{C}$, hydrogen stoichiometry 1.5 , and air stoichiometry 2.5). (a) EIS. (b) Ohmic resistance. 


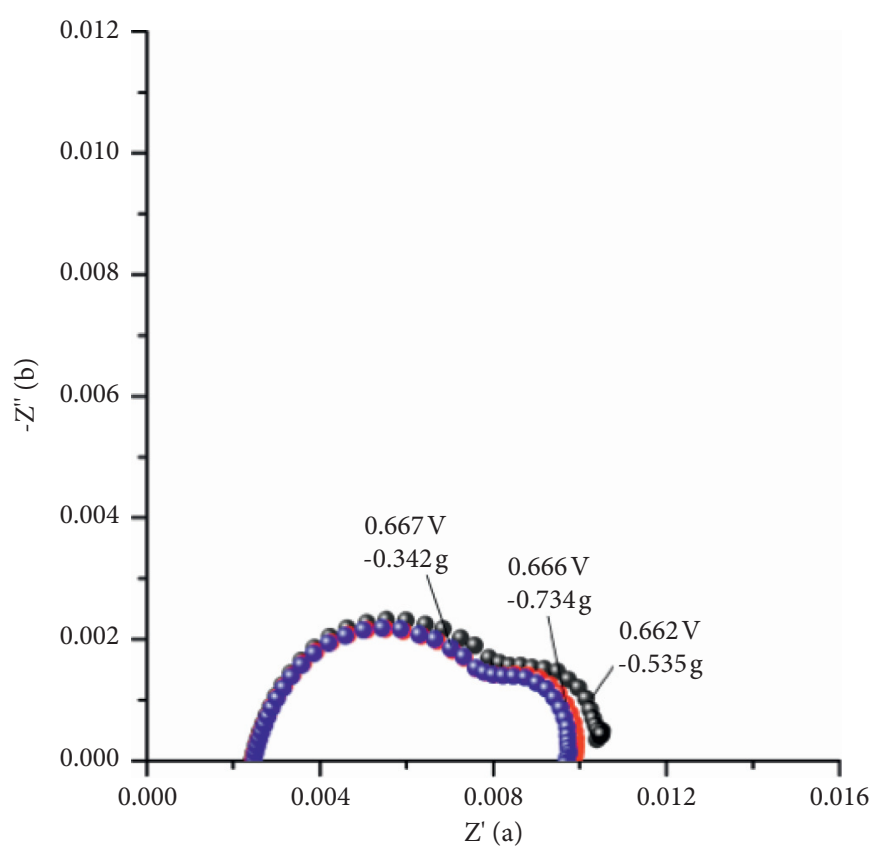

- Hydrogen Stoichiometry 1.05

- Hydrogen Stoichiometry 1.2

- Hydrogen Stoichiometry 2.0

(a)

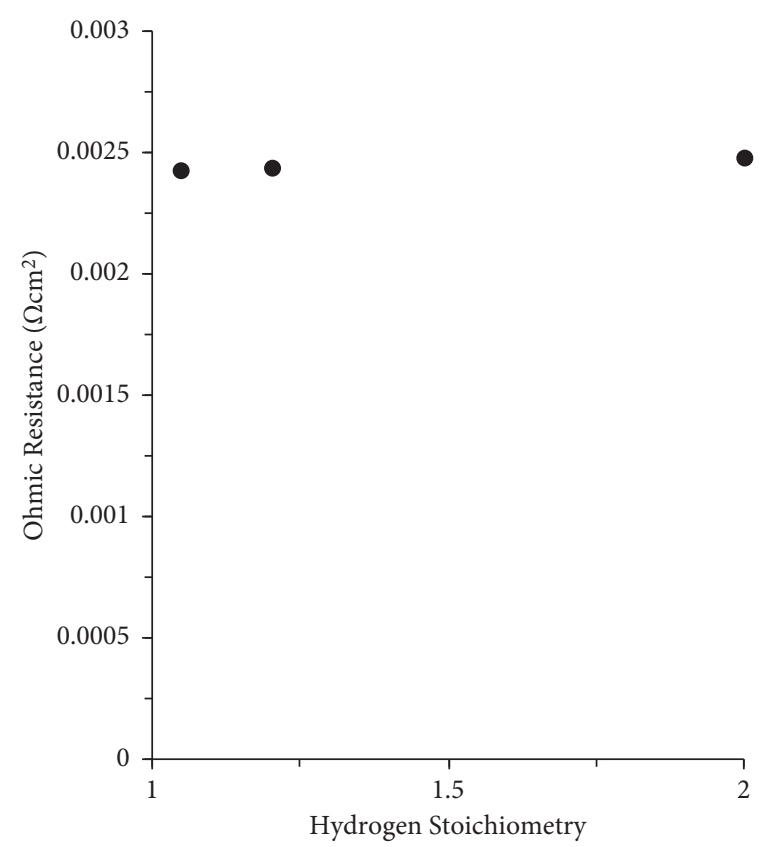

(b)

FIGURE 10: Effect of hydrogen stoichiometry on the voltage, water content in the fuel cell, EIS, and ohmic resistance (inlet gas temperature $75^{\circ} \mathrm{C}$, inlet gas humidity $100 \%$, and air stoichiometry 2.5 ). (a) EIS. (b) Ohmic resistance.

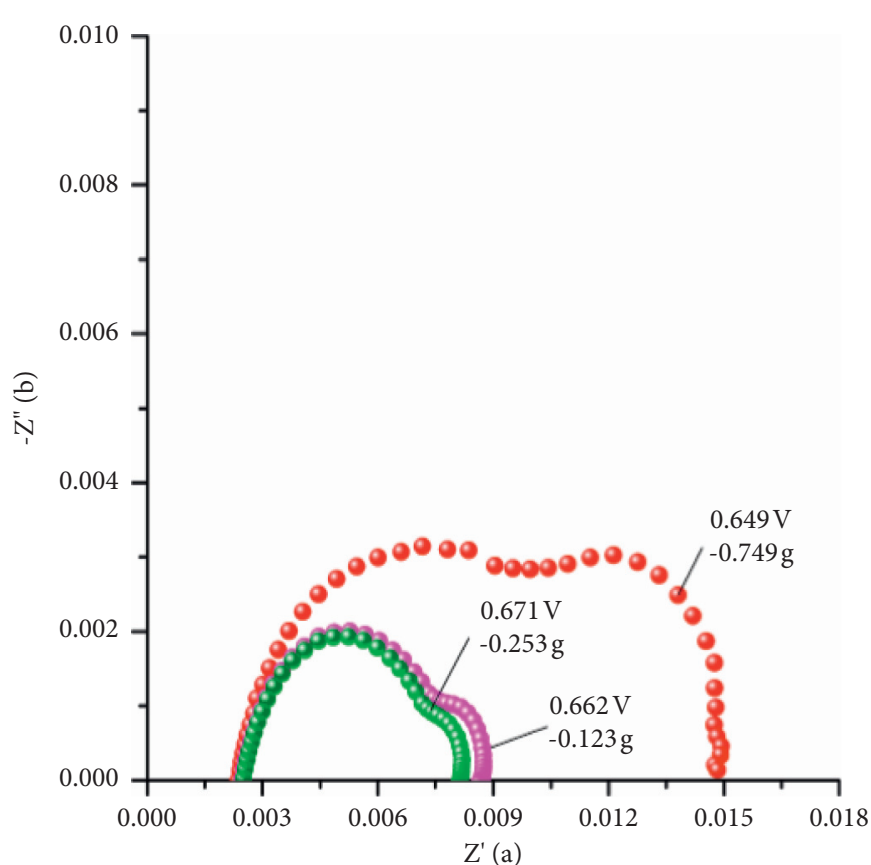

- Air Stoichiometry 2.0

- Air Stoichiometry 3.0

- Air Stoichiometry 3.5

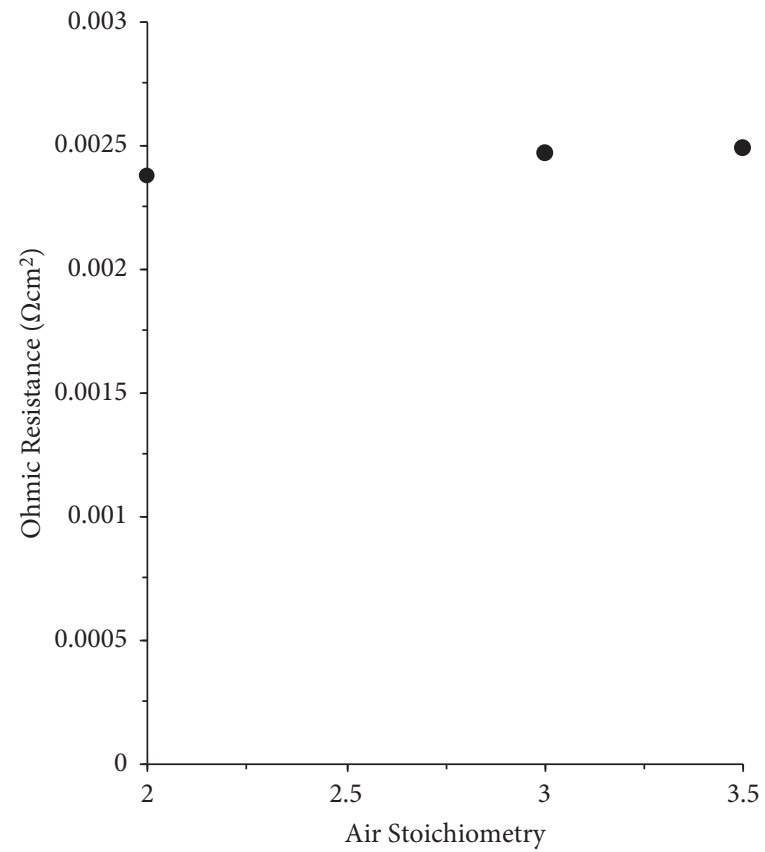

(b)

FIGURE 11: Effect of air stoichiometry on the voltage, water content in the fuel cell, EIS, and ohmic resistance (inlet gas temperature $75^{\circ} \mathrm{C}$, inlet gas humidity $100 \%$, and hydrogen stoichiometry 1.5 ). (a) EIS. (b) Ohmic resistance. 
and the generation rate of water is fast. Besides, the ohmic resistance is relatively not influenced at an air stoichiometry of 2.0-3.5.

\section{Conclusions}

Improving the durability and performance though studying the water balance issue is needed for the largescale commercialization of the PEMFC. The phenomena of "drying" and "flooding" are avoided in order to prevent the performance degradation of the fuel cell. Consequently, the visualization platform of the single fuel cell and the water balance model are built to investigate the water transport mechanisms. Firstly, the visualization platform of the single fuel cell is established. Then, the water balance model of PEMFC is proposed. The change rate of water content in the fuel cell is calculated, and the reliability of the water balance model is verified through the experiment data. Additionally, the water state in the fuel cell is observed online to assist the research of water transport mechanisms. Finally, the effects of inlet gas temperature, inlet gas humidity, and hydrogen/air stoichiometry on the EIS, the voltage, and the water content in the fuel cell are obtained, respectively. The corresponding relationship between the performance and the water content in the fuel cell is set up. The effect of inlet gas temperature on the fuel cell performance is in volatility. The fuel cell performance increases with the increase in inlet gas humidity and hydrogen/air stoichiometry. The water content in the fuel cell has some evident fluctuations by inlet gas temperature and hydrogen/air stoichiometry. The water content in the fuel cell increases with the decrease in inlet gas humidity. The blank of the online evaluation system for the water balance of the fuel cell is filled.

\section{Nomenclature}

$M:$ Molecular weight
$m:$ Amount $(\mathrm{g})$
$p: \quad$ Pressure $(\mathrm{Pa})$
$R: \quad$ Universal gas constant $\left(\mathrm{J} \cdot \mathrm{mol}^{-1} \cdot \mathrm{K}^{-1}\right)$
$T: \quad$ Temperature $(\mathrm{K})$
$t: \quad$ Running time $(\mathrm{s})$
$V: \quad$ Volume flow $\left(\mathrm{m}^{3} \cdot \mathrm{s}^{-1}\right)$
Greek symbols
$\rho:$ Density $\left(\mathrm{kg} \cdot \mathrm{m}^{-3}\right)$
$\varphi:$ Relative humidity
Subscripts
air: Air
out: Outlet
$\mathrm{H}_{2}: \quad$ Hydrogen
gen: $\quad$ Generated by the electrochemical reaction
in: $\quad$ Inlet
l: $\quad$ Left
water: Water
gas: $\quad$ Gas
vp: $\quad$ Water vapor pressure
sat: $\quad$ Saturation.

\section{Data Availability}

The data that support the findings of this study are available from the corresponding author upon reasonable request.

\section{Conflicts of Interest}

The authors declare no conflicts of interest.

\section{References}

[1] O. S. Ijaodola, Z. El-Hassan, E. Ogungbemi et al., "Energy efficiency improvements by investigating the water flooding management on proton exchange membrane fuel cell (PEMFC)," Energy, vol. 179, pp. 246-267, 2019.

[2] Z. Wang, Y. Zeng, S. Sun, Z. Shao, and B. Yi, "Improvement of PEMFC water management by employing water transport plate as bipolar plate," International Journal of Hydrogen Energy, vol. 42, no. 34, pp. 21922-21929, 2017.

[3] J. St-Pierre, D. P. Wilkinsor, and S. Knights, "Relationships between water management, contamination and lifetime degradation in PEFC," Journal of New Materials for Electrochemical Systems, vol. 3, no. 2, pp. 99-106, 2000.

[4] M. A. Hickner, C. H. Fujimoto, and C. J. Cornelius, "Transport in sulfonated poly(phenylene)s: proton conductivity, permeability, and the state of water," Polymer, vol. 47, no. 11, pp. 4238-4244, 2006.

[5] J. Stumper, M. Löhr, and S. Hamada, "Diagnostic tools for liquid water in PEM fuel cell," Journal of Power Sources, vol. 143, no. 1-2, pp. 150-157, 2005.

[6] Y. Sone, P. Ekdunge, and D. Simonsson, "Proton conductivity of nafion 117 as measured by a four-electrode AC impedance method," Journal of the Electrochemical Society, vol. 143, no. 4, pp. 1254-1259, 1996.

[7] W. Chen, Study on Water and Gas Transport of PEMFC, Wuhan University of Technology, Wuhan, China, 2010.

[8] X. Liu, H. Guo, F. Ye, and C. F. Ma, "Water flooding and pressure drop characteristics in flow channels of proton exchange membrane fuel cells," Electrochimica Acta, vol. 52, no. 11, pp. 3607-3614, 2007.

[9] W. He, G. Lin, and T. Van Nguyen, "Diagnostic tool to detect electrode flooding in proton-exchange-membrane fuel cells," AIChE Journal, vol. 49, no. 12, pp. 3221-3228, 2003.

[10] R. Satija, D. L. Jacobson, and M. Arif, "In situ neutron imaging technique for evaluation of water management systems in operating PEM fuel cells," Journal of Power Sources, vol. 129, no. 2, pp. 238-245, 2015.

[11] Y. Yang, Design and Implementation of Fuel Cell Water Management Aided Software Based on CT Visualization Technology, Beijing University of Posts and Telecommunications, Beijing, China, 2018.

[12] W. Yi, The Study of Water Transport Process in the Flow Channel of Proton Exchange Membrane Fuel Cell, Wuhan University of Technology, Wuhan, China, 2018.

[13] K. Tüber, D. Pócza, and C. Hebling, "Visualization of water buildup in the cathode of a transparent PEM fuel cell," Journal of Power Sources, vol. 124, no. 2, pp. 403-414, 2003.

[14] D. Spernjak, A. K. Prasad, and S. G. Advani, "Experimental investigation of liquid water formation and transport in a transparent single-serpentine PEM fuel cell," Journal of Power Sources, vol. 170, no. 2, pp. 334-344, 2007.

[15] H. Guo, J. Zhao, and R. Liu, "Experimental study of performance of proton exchange membrane fuel cells in short- 
term microgravity condition," Journal of Engineering and Thermophysics, vol. 30, no. 8, pp. 1376-1378, 2009.

[16] C. Wang, M. Hu, and S. Ruan, "Research on performance differences of PEMFCs using visualization techniques," Chinese Journal of Power Sources, vol. 39, no. 3, pp. 479-483, 2015.

[17] S. Ruan, M. Hu, and N. Ouyang, "Visualization design and optimization of transparent PEM fuel cell," Chinese Journal of Power Sources, vol. 40, no. 7, pp. 1372-1374, 2016.

[18] H. Huang, J. Zhang, and T. Hu, "Visualization study on parallel flow field of proton exchange membrane fuel cell," Jiangsu Science \& Technology Information, no. 3, pp. 52-54, 2017.

[19] S. S. L. Rao, A. Shaija, and S. Jayaraj, "Performance analysis of a transparent PEM fuel cell at theoptimized clamping pressure applied on its bolts," Materials Today: Proceedings, vol. 5, no. 1, pp. 58-65, 2018.

[20] Y. Wu, H. Liu, and Y. Wu, "Transport mass mathematical model and water management of PEM fuel cells," Hydrogen Energy, vol. 2, 2000.

[21] S. Hong and H. Liu, Transport Mass Mathematical Model and Water Management of PEM Fuel Cells, Beijing Society of Astronautics; China Association for Hydrogen Energy, Beijing, China, 2008.

[22] M. Kellegoz, "Modelling, simulation and testing of a proton exchange membrane fuel cell," International Journal of Advanced Research in Engineeringe Management, vol. 2456, pp. 20-24, 2020.

[23] X. Zhao, Y. Yang, and D. Hao, "Analysis of water transfer mechanism of vehicle fuel cell," Automobile Parts, vol. 11, pp. 58-62, 2020.

[24] H. Zhang, C. Shen, and F. Han, "Water balance of proton exchange membrane fuel cell," Chemistry, vol. 11, pp. 10261032, 2011.

[25] D. W. Mulyazmi, W. R. W. Daud, E. H. Majlan, and M. I. Rosli, "Water balance for the design of a PEM fuel cell system," International Journal of Hydrogen Energy, vol. 38, no. 22, pp. 9409-9420, 2013. 